Journal of Southeast Asian

\title{
Role of Family, Culture, and Peers in the Success of First- Generation Cambodian American College Students
}

\author{
Jennifer Tang \\ California State University, Long Beach, jenntang14@gmail.com \\ Simon Kim \\ California State University, Long Beach, Simon.Kim@csulb.edu \\ Don Haviland \\ California State University, Long Beach, Don.Haviland@csulb.edu
}

Follow this and additional works at: https://docs.lib.purdue.edu/jsaaea

Part of the Asian American Studies Commons

\section{Recommended Citation}

Tang, Jennifer; Kim, Simon; and Haviland, Don (2013) "Role of Family, Culture, and Peers in the Success of First-Generation Cambodian American College Students," Journal of Southeast Asian American Education and Advancement. Vol. 8 : Iss. 1, Article 2.

DOI: 10.7771/2153-8999.1057

Available at: https://docs.lib.purdue.edu/jsaaea/vol8/iss1/2

This document has been made available through Purdue e-Pubs, a service of the Purdue University Libraries. Please contact epubs@purdue.edu for additional information.

This is an Open Access journal. This means that it uses a funding model that does not charge readers or their institutions for access. Readers may freely read, download, copy, distribute, print, search, or link to the full texts of articles. This journal is covered under the CC BY-NC-ND license. 


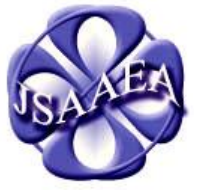

Volume 8 (2013)

\section{Journal of Southeast $A$ sian $A$ merican \\ Education \& Advancement \\ WWW.JSAAEA.org}

A peer-reviewed

scholarly journal

published by the

National Association

for the Education \&

Advancement of

Cambodian, Laotian, and Vietnamese Americans (NAFEA)

\author{
Role of Family, Culture, and Peers in the Success of \\ First-Generation Cambodian American College Students \\ Jennifer Tang, Simon Kim, and Don Haviland \\ California State University, Long Beach
}

\begin{abstract}
Cambodian American college students are often overlooked in academe because of the model minority myth. The stereotype overshadows the challenges and heterogeneity in the Asian American and Pacific Islander population. This exploratory study examined the experiences of 13 first-generation Cambodian American college students at a large, public institution in California. Findings revealed that, despite challenges associated with being first-generation, students drew upon various forms of social and cultural capital. Accessing this capital gave them validation from their parents and peers, created a sense of belonging to the college community, and helped them fashion a rich and successful college experience.
\end{abstract}

KEY WORDS: Cambodian American, College Experience, Higher Education, Validation, Qualitative Research, Southeast Asian, Cultural Capital, FirstGeneration

\title{
Introduction
}

College-going rates are up considerably for all students over the last 30 years (National Center for Education Statistics [NCES], 2010). Although this progress is encouraging, a persistent and pernicious degree attainment gap exists between Asian and White students and African American and Hispanic students. For example, there is an 18-percentage-point gap between the six-year graduation rates of White (59\%) and African American (41\%) students. Similarly, the gap between Asian American (66\%) and Hispanic (47\%) students is 18 percentage points (NCES, 2010).

These statistics give the appearance that Asian American students are successful and not educationally disadvantaged in higher education (Astin, 1982; Nakanishi, 1995). In fact, Asian Americans are seen as the model for other minorities to follow to overcome barriers in achieving the American dream. They are no longer considered as an "underrepresented" group in higher

\footnotetext{
(c) SOMERIGHISRESERVEDReaders are free to copy, display, and distribute this article, as long as the work is attributed to the author(s) and the Journal of Southeast Asian American Education \& Advancement, it is distributed for noncommercial purposes only, and no alteration or transformation is made in the work. More details of this Creative Commons license are available at http://creativecommons.org/licenses/by-nc-nd/3.0/. All other uses must be approved by the author(s) or JSAAEA.
}

Journal of Southeast Asian American Education \& Advancement, Vol. 8 (2013) 
education, nor a group that needs any public social and educational services (Lee, 1996). However, not all Asian Americans are the same and there are tremendous discrepancies in student achievement and degree attainment across Asian American ethnic groups. Disaggregated data of Asian American students' educational attainment clearly shows that the model minority image is a myth and hides academic challenges faced by certain Asian American subpopulations (Hune, 2002; Ngo \& Lee, 2007). More specifically, the college persistence and graduation rates for Southeast Asian American students remain far below the national average (U.S. Census, 2011). Approximately 49\% of Asian Americans earned a bachelor's degree or higher, exceeding the national rate of $28.2 \%$, but the Cambodian (16.0\%), Hmong (14.8\%), Laotian (13.2\%), and Vietnamese (25.5\%) populations earned significantly lower rates of postsecondary degrees (U.S. Census, 2011).

Despite these challenges and academic disparities, research on Southeast Asian American students in higher education is relatively scarce (Museus \& Kiang, 2009; Wright \& Boun, 2011). In fact, researchers have constantly had to justify the inclusion of Asian Americans in higher education discussions and deconstruct the model minority myth for the last two decades (Museus \& Chang, 2009).

In particular, Southeast Asian Americans-Cambodian Americans, Vietnamese Americans, Hmong Americans, and Lao Americans - are unique in that the majority of them came to the United States as refugees, not as immigrants. For example, Cambodian refugees escaped the Khmer Rouge genocide in the 1970s before resettling to the U.S. with minimal resources and educational attainment (Takaki, 1998). Southeast Asians are disproportionately poor and less educated compared to other Asian American ethnic groups (Reeves \& Bennett, 2004). They also face a greater language barrier than other Asian Americans because of their limited exposure to English (Southeast Asia Resource Action Center, 2011; Wright \& Boun, 2011). Most Southeast Asians are "linguistically isolated," living in ethnic enclaves or communities predominantly of the same background (Brydolf, 2009; Hune, 2002; Ngo, 2006). Approximately $70 \%$ of Asians speak another language other than English and the Cambodian (77.1\%), Hmong $(88.7 \%)$, Laotian $(78.4 \%)$, and Vietnamese $(85.0 \%)$ populations have higher rates of individuals over five years old speaking their native language (U.S. Census, 2011). The minimal opportunities to speak English for Southeast Asians caused by their homogenous neighborhoods impede their English language abilities.

Thus, while Asian Americans have grown faster than any other racial group in the United States from 2000-2010, and the total population is expected to reach 40 million by 2025 (Teranishi, 2012; U.S. Census, 2011), there is a subgroup within this population that struggles academically and is not receiving adequate attention (Museus \& Kiang, 2009; Teranishi, 2002). The research on retention and persistence seldom includes Asian Americans even though Southeast Asians encounter educational challenges (Chhuon \& Hudley, 2008; Ngo \& Lee, 2007; Yeh, 2004). For example, Cambodian American students who struggle academically may not express their struggles for fear of being ridiculed by peers or disappointing their teachers (Chhuon \& Hudley, 2011; Tang \& Kao, 2012). As the ethnic/racial group increases and becomes more diverse, underrepresented Asian Americans such as the Southeast Asians, risk falling further behind if they are denied resources and support.

The purpose of this exploratory study was to understand the college experiences of firstgeneration Cambodian American college students. First-generation students describe students whose parents have not graduated from college. Most research on Cambodian Americans does not capture their educational experiences and the few studies that focus on the academic 
experiences of the group only examine their high school experiences (Chhuon, Desalmas, \& Rinthapol, 2010; Chhuon \& Hudley, 2010, 2011). This study examines the obstacles of firstgeneration Cambodian American college students and the extent to which they are supported by their parents, an ethnic-based student organization, and peers. The results of this study contribute to the limited knowledge of Cambodian Americans in higher education and challenge the conventional perception of Asian Americans as the model minorities.

\section{Conceptual Framework}

Rendon's (1994) Validation Theory and Yosso's Community Cultural Wealth Theory (2005) discuss the abilities of marginalized communities to succeed despite their challenges. Both theories are important to understanding the experiences of Cambodian American college students. Cambodian Americans are generally perceived as troublemakers and not scholars (Chhuon \& Hudley, 2011; Ngo, 2006), therefore, they are not expected to succeed academically. The framework employed for this study allows for the examination of the students' college experiences not only through observing challenges they face, but also the extent to which validation is present in those experiences and the capital upon which students draw to succeed in college.

Rendon's (1994) Validation Theory suggests that traditionally underrepresented groups in higher education, such as Cambodian American students, enter a higher education system that does not always recognize their backgrounds, talents, and experiences. However, validation both in-class and out-of-class can help to acknowledge these strengths and assets, as well as help the students develop a sense of belonging in the university. With this validation, students can be powerful and successful learners (Rendon, 1994).

Validation is defined as, "an enabling, confirming and supportive process initiated by inand out-of-class agents that foster academic and interpersonal development" (Rendon \& Jalomo, 1995, p. 9). In-class validation includes positive interactions with faculty that foster student learning. For example, professors are validating agents, especially those who demonstrate their care for students by working with students individually. Out-of-class validation encompasses the support of student's spouse/partner, friends, and family. For example, family's encouragement motivates students to excel in school and believe in their academic abilities.

Students transition to college academically and socially through the help and support of these validating agents. And when they develop the sense of belonging in the college community that comes with validation, they develop into powerful learners, gain a new attitude towards learning, and overcome obstacles because they perceive the learning as meaningful. Validation is most effective during the earlier stages of the student's collegiate career, specifically the first year (Rendon, 1994).

This study is also informed by the Community Cultural Wealth Theory (Yosso, 2005). This theory echoes Rendon (1994), noting that students from marginalized communities have not just challenges in succeeding in higher education, but also have great sources of strength and capital that must be recognized and drawn upon in college. Notably, the community cultural wealth model posits six forms of capital held by students from traditionally underrepresented groups: aspirational (having hope for the future despite challenges), linguistic (multilingualism), familial (connection to community), social (interpersonal relationships), navigational (strategies

to navigate hostile environments), and resistant capital (skills developed from oppositional behavior that challenges inequality) (Yosso, 2005). 


\section{Methodology}

This qualitative study examined the following research question: What are the personal, institutional, and/or community forces that shape the experiences of Cambodian American college students at a large, comprehensive university? Participants in this study self-identified as Cambodian American and attended Sunnyview University (a pseudonym), in Fall 2012. Table 1 presents the characteristics of the 13 Cambodian American undergraduate student participants in this study, including nine upper classmen and four lower classmen. The students ranged from ages 19-22 and were American-born, lived with their parents, and commuted to school. Seven of the students worked at least part-time and 10 of the students' household incomes were $\$ 50,000$ or lower. Twelve students reported their parents did not hold a college degree and, of these twelve students, the parents of five attained a high school education or lower. These students represented a diverse range of majors from the engineering, arts, business administration, and health and human services.

Table 1

Participants in the Study

\begin{tabular}{lcccc} 
Name & Age & Gender & $\begin{array}{c}\text { Academic } \\
\text { Standing }\end{array}$ & Household Income \\
\hline Allison & 22 & Female & Senior & $\$ 30-50 \mathrm{k}$ \\
Brian & 19 & Male & Sophomore & $\$ 100 \mathrm{k}$ \\
Cindy & 21 & Female & Senior & $\$ 30-50 \mathrm{k}$ \\
Crystal & 19 & Female & Sophomore & Under $\$ 30 \mathrm{k}$ \\
Jessica & 20 & Female & Junior & Under $\$ 30 \mathrm{k}$ \\
John & 20 & Male & Junior & N/A \\
Kiko & 19 & Female & Sophomore & $\$ 80-\$ 100 \mathrm{k}$ \\
Mark & 21 & Male & Junior & Under $\$ 30 \mathrm{k}$ \\
Michelle & 22 & Female & Senior & $\$ 30-50 \mathrm{k}$ \\
Samantha & 20 & Female & Junior & $\$ 30-50 \mathrm{k}$ \\
Sophie & 22 & Female & Junior & Under $\$ 30 \mathrm{k}$ \\
Stephanie & 21 & Female & Senior & Under $\$ 30 \mathrm{k}$ \\
Steve & 19 & Male & Sophomore & Under $\$ 30 \mathrm{k}$ \\
\hline
\end{tabular}

A majority of the students were recruited through the Cambodian student organization, which will be referred to as the Cambodian Student Club (CSC) in this study. Each participant was interviewed for approximately one hour in a private site on campus and students chose their own pseudonym to ensure confidentiality. Interestingly, all but one of the interviewees opted for European names (one chose a Japanese name) as opposed to Cambodian names even though half of them had Cambodian first names. Their choice in pseudonyms raises a question about their 
perception of preferred names and how this relates to their cultural identity, although this question is beyond the scope of this study. The interview questions were purposeful and designed to address the research question. The use of semi-structured questions allowed the participants to answer freely, and the researcher to follow-up on unanticipated comments or insights.

The interview data were transcribed and analyzed using first and second cycle coding methods identified by Saldaña (2009). In the first cycle of data analysis, codes were assigned to the data as a way to organize ideas, phrases, and experiences that shared similar traits and characteristics. Subsequently, the author employed a second cycle of coding to reassemble the codes to develop themes. The first author (Tang) took the lead in the data analysis, and the third author (Haviland) served as a peer debriefer.

Sunnyview is a large, comprehensive institution, and was ideal for this study because of its location near a Cambodian community in California. The University enrolled over 27,000 undergraduate students in Fall 2010, of which approximately $23.5 \%$ of the students selfidentified as Asian American. The first year persistence rates (students continuing to their second year) ranged from 80-90\% for Cambodian Americans, which were slightly lower than Southeast Asian students on campus overall. The 2004 Cambodian American cohort showed a one-year persistence rate of $85.9 \%$, but the cohort's six-year graduation rate was $35.2 \%$, which was lower than their Southeast Asian peers (53\%) on campus. The Cambodian American students at this institution were also in need of remedial courses. Nearly $70 \%$ of the first-year Cambodian American students admitted in 2010 had to enroll in remedial English class. Most of the Cambodian American students were born in the United States, but many of them struggled in English.

\section{Positionality and Trustworthiness}

Data collection and analysis were conducted by the first author (Tang), a Chinese American whose family escaped Vietnam in the late 1970s. As a second generation Chinese American who grew up with monolingual parents, the first author struggled with English language literacy and experienced the negative effects of the model minority stereotype in college. Due to the dual identities, the first author analyzed the data through two lenses: a) as a child of refugee parents who came to the United States after the war; and, b) as an East Asian American.

The first author employed several strategies to ensure a credible account. During interviews, she strived to refrain from sharing personal information that might influence the students' responses. During the data analysis phase, the third author (Haviland) was used as a peer debriefer to ensure the integrity of the coding structure (Lincoln \& Guba, 1985). In addition, findings and interpretations were member checked with two study participants (Lincoln \& Guba, 1985), who validated the first author's interpretations.

\section{Findings}

Cambodian American students' pathway into and through college reflected the journey typical of many other populations of first-generation college students. Their parents were often unable to support them with many of the details of education, and students generally had to navigate the journey on their own. However, parents were very supportive of the students' pursuit of higher education and sought to be engaged in the process. Students both valued such support and found 
it presented challenges. They also found great value in their involvement in an ethnic-based student organization and in the support of peers.

\section{The Educational Journey of First-Generation Cambodian American Students}

Similar to other first-generation college students, many Cambodian American students could not depend on their parents to help with school for a variety of reasons, including lack of familiarity with the U.S. school system as well as limited English proficiency.

Students noted that limited language skills on their parents' part, as well as lack of familiarity with the American education system, meant they were often on their own during the pre-college educational journey. For example, students discussed their parent's lack of English skills and the related inability to help them with their academics. Cindy said neither of her parents held a college degree nor were they able to provide academic support, so she had to learn to be independent and find answers elsewhere. She explained, "They didn't really help me in any school work because they were too busy working or they couldn't understand English."

Apart from language issues, lack of familiarity with the educational system in general also posed problems. After Sophie explained that her parents were unfamiliar with the American school system, she was asked who guided her through elementary and high school. She responded:

Nobody. That's why I didn't care about school ... they never scolded me or anything. They're just like 'just do your best, okay?' That's about it. They don't pester me if I'm doing my homework ... I wished they would put their foot down a bit more when I was younger. I had to learn on my own.

Sophie's dad had attended a trade college and was unable to offer her advice for a traditional higher education pathway; therefore, it was her responsibility to navigate her academics. The lack of accountability and guidance from her parents negatively affected Sophie and delayed her educational pursuit. However, after spending four years in community college, Sophie reevaluated her academic and personal goals and realized the importance of education. From that point forward, the thought of being the first to earn a bachelor's degree in her family motivated her to persist and transfer to a four-year institution.

Parents' lack of familiarity with the American K-12 and college system meant students were sometimes at the mercy of high school counselors-some of whom provided poor academic advice and jeopardized the students' chances of meeting the admission requirements for college. Steve remembered the impact of this type of advising, "My counselor kind of messed up my classes because I needed one more science class so I can get into UC." He had relied on his counselor because his parents were unfamiliar with higher education. He recognized, "Family is always there for you, but since they didn't go to college, it's kind of hard for them to help me because they don't understand where we come from or what we're doing." Steve thought his counselor's mistake cost him admission into other, perhaps better colleges.

In Mark's case, he felt the quality of advising affected his college application process: "Even though there was a guidance counselor, they focused predominantly on your academic schedule for high school, for what you're going to pick, classes for the next semester or next year. They didn't really focus on college." Several of the participants felt unprepared for college because they were unsure of the expectations and had limited knowledge about college in 
general. Their experiences illustrated the different challenges of first-generation Cambodian American students and the impact on their college access.

Participants' parents often lacked the capital to assist the students in their academic attainment and students were left to navigate the journey through school and to college on their own. However, being first-generation college students motivated them, and they drew on aspirational capital to shape a desire to succeed for themselves and their families despite obstacles.

\section{Parental Support and Expectations}

Parents' refugee background shaped students' value in education and motivated them to pursue a college degree. Parents encouraged students to attend college in hopes that they would achieve a better life in the future. Students drew on their aspirational and familial capital to achieve more. For example, Allison was aware of the sacrifices her family experienced when they left Cambodia: "That's not where they saw the future for us ... they came to America for a second chance to build a better life because they knew there were more opportunities here." Students strived to achieve more because their families escaped a war in Cambodia and arrived to the U.S. with minimal resources. Mark explained, "Coming from a background with a lot of struggles and hardships really sets your mindset in the aspect you have nothing to lose because you have nowhere to go but up." Their family background resonated with the students and encouraged them to aspire for higher education.

While the instrumental support (e.g., with homework) that parents could provide was limited, they encouraged the students to pursue higher education. And once the students were in college, parents supported them by providing financial assistance and emotional support. For example, Samantha depended on her parents to pay for tuition and other expenses. She was mindful of the challenges her parents endured before coming to the U.S. and the costs of her college education. Thus, she stressed her responsibility to do well in school with her parent's help:

If I don't study, then it's on me, not them. They're just there to support me in what I do. If I didn't want to study then that's up to me, not them, so I pushed myself to study and get good grades.

Samantha's parents offered emotional support by encouraging her to work hard in school. However, she held herself accountable for her study habits. The combination of her motivation and her parent's encouragement contributed to her college experience and success.

Additionally, Stephanie's parents encouraged and motivated her to pursue higher education even though they never earned a high school education in the U.S.; familial capital was an asset to Stephanie's life. She received financial aid to pay for college, but her parents paid for expenses such as monthly household bills. When Stephanie started to work, she wanted to pay for her own expenses to assist the family. Interestingly, she faced opposition from her parents who encouraged her to concentrate on graduating from college before worrying about finances:

I'm so grateful for my parents. Sometimes I'll try to help out and they're like 'no' so they really try to watch out for me ... I try to support them that way but they're like 'no, 
don't worry about it so they're supportive in that way too because they don't ever want me to be financially burdened by anything.

Students such as Stephanie discussed their parents' tendency to take care of them as they pursued education and expressed how appreciative they were of their families. For parents, it was important to help the students while they were in college.

Family's encouragement to focus on school was an important motivator for the students. Steve worked hard to maintain his grades and his parents' reminders helped him to stay on track. His parents could not help with his schoolwork, but they emphasized constantly the importance of education and encouraged him to study hard, which prompted Steve to get on his "study grind" and prepare for his exams. Similarly, Crystal's parents prevented her from falling behind in her work. She explained, "If I mess around with my school and I'm kind of getting bad grades ... they'll kind of tell me like 'oh, what am I doing? 'Why am I like messing around so much? 'You should really study." Again, the parents checked on the students and the students responded by trying their best to finish their work.

Yet for some students, parents' engagement in their education created a sense of burden or stress. For example, questions about grades or academics could add pressure. Cindy's parents tried to prevent her from stressing and did not interrupt her and allowed her to focus on her studies. However, Cindy felt pressure to earn A's and achieve academic success, and there were instances when she did not let her mom see her grades because she wanted to avoid seeing her mom's disappointment.

Similarly, three of the students mentioned their "super senior" status because they were enrolled in school beyond the traditional four years. Although their parents held minimal knowledge about college, they knew college was only supposed to last for four years. Thus, when the students stayed in school beyond the fourth year, parents showed signs of concern or impatience as they waited for the students to graduate.

In part because of parents' expectations that students earn their degrees in a timely manner, parents sometimes were not supportive of students' engagement on campus. For example, among the 11 participants who were in an ethnic-based student organization, four students said their families opposed their campus involvement. One of the reasons was the parents' perceived value of the students' involvement. For parents, time was better spent with family or for school purposes. Jessica recalled her dad's thoughts about joining the clubs: "[He thinks] it's more important to support the household than doing something like extracurricular activities. It wasn't something that was seen as top priority." Additionally, she noted the mistrust in the community when her dad objected to her involvement with other Cambodian Americans: "I guess there was mistrust with the community back then. There were people who were trying to help out, but they ended up being traitors. They ended up taking people's money and then leaving the country." Jessica's father's suspicion of the community might be influenced by the genocide they experienced when Cambodians killed their own people. The other three students who encountered disproval from their family expressed similar perspectives. As a result, several of the students minimized their actual participation in the club to prevent further disapproval from their families.

In addition, some students recalled parents trying to persuade them into pursuing a different career. When Cindy first started college, her parents encouraged her to study biology, but she was not interested in the major and struggled: "My parents wanted me to be a doctor, so I did Bio ... I was suffering so much. I even cried during classes. I was like, 'I can't do this 
anymore." Cindy realized she was pursuing a major that was unfit for her and switched majors several times before finding a field of her interest.

While perhaps less traumatic, others shared similar pressures. John's dad recommended that he choose "something science-y" when he declared a philosophy major. John understood science would be a more lucrative career choice, but his passion was philosophy and he continued his studies despite his dad's suggestion since it was his career. Kiko also remembered her parents trying to "brainwash" her into being a pharmacist when she was younger. After some consideration, she decided to pursue art and her parents supported her decision. Parents often supported the students as much as they could, but worried about the students' future job opportunities when they selected certain majors.

Students' background as children of refugees motivated their college pursuit. Parents emphasized the importance of education and supported the students regardless of their understanding of the education system. Parents encouraged students to follow a college academic path as the first generation to have an opportunity to attain higher education. At the same time, parental involvement sometimes created pressures (for grades, to graduate, to pursue particular majors, to not be involved in student organizations) that students had to navigate and manage.

\section{Role of the Ethnic-Based Student Organization}

Nearly all of the students in this study were active members of an ethnic-based student organization. Their desire to identify as Cambodian Americans led to several implications in their lives as they embraced their culture. Students confronted situations with people who were oblivious to their cultural background and those interactions added to their feelings of being a minority.

First, most of the students exhibited a sense of cultural pride and worried about their culture diminishing as fewer people recognized Cambodian Americans. Steve noticed the lack of interest younger Cambodian Americans showed in learning their own culture. Allison described Cambodian Americans who seemed to ignore their own heritage in favor of other Asian cultures:

A lot of students, Khmer or not, they want to be involved with Korean pop culture. They want to be involved with the Japanese pop culture, but you never see another race interested in the Cambodian culture.

Other students also mentioned Cambodian American peers who felt ashamed of their upbringing and being of Cambodian descent. Students in this study were connected to their community and strived to preserve their culture. They perceived, however, a decrease in cultural awareness that affected the Cambodian American community as a whole; this perception made these students more passionate about increasing their visibility.

Second, students encountered interactions where they had to validate their culture or clarify their background. Although the students were members of the CSC, they expressed feeling like minorities and being underrepresented on campus compared to other groups. Steve mentioned, "Most of the Asian ethnicities were Chinese, Filipino, and Koreans because that's what everybody knows." Any discussions of Cambodian culture or affiliations sparked the students' interests. Stephanie added to this idea when she talked about her reactions to references about Cambodians: 
When I hear a professor say something about Cambodia or Cambodians ... because you always hear Chinese or Korean, I get excited even if I see it anywhere else ... just to let them know we're there, we're part of the Asian community there and everything and "hey, include us."

Samantha recalled informing people she was Cambodian: “They're like 'oh' and they just move on or 'oh, what's that?' Some people don't know of Cambodia." Similar to other students, Samantha was not bothered by the constant inquiries and was open to sharing her culture if others asked since most people showed limited knowledge on Cambodia. However, such interactions contributed to their feelings of being overlooked.

Joining an ethnic-based student organization allowed students to embrace their heritage, learn their culture, and establish a strong sense of community on campus. All of the students were second generation (U.S.-born), but they had different experiences and varied in their understanding of the traditions and history. Moreover, the students generally felt underrepresented compared to other groups on campus. As a result, the organization gave them a space to learn and practice their customs, and to connect with their peers. The initial thoughts about being in the organization emerged when participants wanted to learn more about their culture. Kiko reflected on her decision to become a member:

I joined CSC so I could learn more about my culture and get more in touch with it because at home I don't speak Cambodian. I always talk back in English, but my parents speak to me in English too ... they always say "oh, it would be nice if you learned Khmer or something."

Like many students, Kiko thought joining the organization would increase her knowledge about Cambodian culture and subsequently improve her family relations at home. Additionally, Michelle credited the organization for helping her increase her Khmer speaking abilities and her knowledge of the culture. The cultural component was important to the students because it allowed them to relate to their parents and peers while still learning about their heritage.

Students reported that the CSC also provided a sense of community and gave them a voice on campus. Steve mentioned the strong bond the CSC built for him and his peers when they needed support on campus. The club events could become quite stressful and time demanding, but he remained an active member in the organization. The CSC acted as the space for Cambodian American students to gather with people of similar backgrounds. Students in the CSC produced an annual culture show that tied the students, their families, and the community together. The student production meant a lot to the students and was one of the main reasons most joined and stayed in the organization. Michelle said:

I feel like it's a way to show our audience or the community that we worked really hard on this to show you, that we are trying to learn about our culture and still keep our culture alive with the show.

Not only did the event showcase their culture to the school, it allowed students to share part of their college experiences with their family and other community members.

Students felt underrepresented at Sunnyview University due to the low enrollment of Cambodian Americans and tended to be more drawn to peers who shared their cultural 
background. Thus, they committed their time to the ethnic-based organization to connect with peers who shared their cultural backgrounds and to raise cultural awareness about Cambodia on campus.

\section{Peer Support and Campus Involvement}

Peer support beyond that of peers in the CSC also contributed to the college success of students. Cindy stressed the importance of her support group: "It's pretty important. It's good to know that people do care about you. If I didn't have that, I probably wouldn't study as much, or I probably wouldn't study, but then, it's just that motivation." As Cindy expressed, students relied on one another as support and motivation to succeed academically. Although students were not in the same majors as their friends, the collective effort of studying together helped them in school. Crystal pointed to the significance of peer influences when she credited her close group of friends for her success. She stated, "If I didn't have the friends I do now ... that didn't take education as important, I wouldn't be where I am today." The common background and values with her friends helped her feel "more at place" in school.

Additionally, informal peer mentors provided motivation and guidance to the students. Mark wanted to give up during one of the most difficult times in college and he said, "[My mentor] kept assuring me that I could do it, motivating me, [and] being there emotionally when I was breaking down." Mark's mentor from a service-based organization on campus increased Mark's confidence when he doubted himself. He was comfortable sharing his problems with his friends as opposed to his family members because friends understood him and offered helpful advice. One student in particular credited his mentor (not his family) for his accomplishments. John's mentor, a Sunnyview alumnus, helped John overcome personal challenges and cultivated his interests in philosophy. John explained, "He's a big thing in my life right now. He's very important. I look up to him." John's mentor guided John academically and provided the extra push John needed to concentrate on school. Peers contributed a different type of support than family that enabled students to confront hindrances in college.

Campus involvement beyond the CSC was an important way for students to meet friends who shared common ground and expand their network. Students involved in campus organizations had to learn to balance both academic and campus lives as their schedules became busier, but the two were interconnected. Even as school grew increasingly difficult, none of the students who were in organizations, including CSC, expressed any indications of quitting the group. They stayed involved on campus through student organizations and relied on peer support to remain motivated in school. While parents were not always supportive of the students' participation in non-academic activities, the students remained in their organizations despite their parents' opposition.

\section{Discussion}

The stories and experiences of the Cambodian American students interviewed reflect resilience, determination, and creativity in fashioning a successful college experience for themselves. While the students clearly found the journey to and through college challenging in many ways, they drew on varied resources and their own internal drive for support and to enhance their college experiences. Viewed through the lenses provided by Rendon (1994) and Yosso (2005), it is clear that the students were able to draw upon multiple sources of capital to facilitate their 
journey and that these sources of cultural wealth served as important validating agents for the students. In particular, the students accessed and sought familial, aspirational, social, navigational and linguistic capital as tools to validate and support their college experience in complex and intertwined ways.

\section{Familial and Aspirational Capital}

Family motivated and encouraged students to pursue higher education. Parents clearly recognized the value of a college degree, therefore, they instilled the value of education in the students and expected students to attain higher education. For instance, parents of the students in this study provided consistent non-academic support such as reminding students to focus on school, holding them accountable for studying, and giving them as much financial support as they could. Contrary to other findings on Cambodian Americans (Kiang, 1992; Um, 2003), families in this study did not seem to expect or pressure students to find work while they were in school. In fact, at least one family seemed to actively discourage their daughter (Stephanie) from working while in college. This form of support eliminated additional stress for some of the students since work was a choice and not obligatory.

Closely tied to the familial capital students drew upon was the aspirational capital they demonstrated through their commitment to overcome challenges and persist to earn a college degree. Students such as Allison, Samantha, and Mark demonstrated a keen awareness of the hardships their parents and family had endured, the sacrifices they had made, in coming to the United States and seeking a better life for their children. This recognition helped drive them to persevere despite poor preparation for college, limited advising and support, and occasionally feeling marginalized on campus. Filial piety, a cultural belief to take care of the family and parents, was evident as the students aspired to achieve an education and a career that would honor the sacrifices their parents had made and allow them to care for their family in the future (Leung, Wong, Wong, \& McBride-Chang, 2009). This cultural value of filial piety is aligned with other literature on Cambodian Americans (Chhuon, Hudley, Brenner, \& Macias, 2010; Chhuon, Kyratzis, \& Hudley, 2010).

In these ways, family and aspirations for a better life were intertwined and served as important sources of capital (Yosso, 2005) for the Cambodian American students. Students' aspirations came from a commitment for better lives not just for themselves, but for their families as well, and the belief that college provided a pathway to those lives. Moreover, familial capital served as an important out-of-class validating agent (Rendon, 1994) for the students, affirming that they belonged in college, which they could and should earn a degree, and that doing so would be worth the effort.

At the same time, it was not as if familial support was absolute. Mirroring other research (e.g., CARE, 2011; Teranishi, 2004; Wright \& Boun, 2011), most of the parents in this study were unfamiliar with the American school system and faced language barriers that limited their ability to provide instrumental support to their children in navigating and succeeding in the educational system (Chhuon, Hudley, Brenner \& Macias, 2010). In short, the Cambodian parents lacked the cultural capital to assist their children as fully as some other parents might and the students were often left to navigate the journey on their own.

Moreover, while family members supported participants in their academic pursuits, several parents disapproved of the students' campus involvement and felt that students were wasting their time. Family members generally failed to see the value of students' participation in 
extra-curricular activities as a way to develop critical social capital in college, even though the educational benefits of student involvement, especially for Asian Americans, are clear (Astin, 1984; Chhuon \& Hudley, 2008; Johnson et al., 2007). Students, however, recognized the benefits because the social network strengthened their commitment to school. Thus, the students in this study who faced such opposition were conflicted with their campus commitments. Rather than quitting the organization, most decided not to inform their family of their actual involvement in the organization even as they stayed involved.

\section{Social, Linguistic and Navigational Capital}

If family motivated students to pursue higher education, then peers served as equally important out-of-class validating agents (Rendon, 1994), enabling them to persist in college by providing emotional and academic support. While the role of peers in general was important for students in this study, the role of the CSC as an ethnic student organization was particularly important for these students because it connected them to their language and culture in a way that validated their presence on campus and helped them navigate the college experience. In this study, students appeared intuitively to recognize the value of both social and linguistic capital (Yosso, 2005), and actively sought both out despite resistance from parents.

Extant research has found that Asian Americans are more likely to participate in ethnic/cross-cultural clubs, and that these cultural organizations are vital to the academic success of Cambodian American students (Chhuon \& Hudley, 2008; Johnson et al., 2007). The cultural aspect is intertwined with their college experiences, shapes their social lives, and enables students to adapt to their new learning environment. Since first-generation Southeast Asian students often lack a sense of belonging on campuses due to low enrollment rates (Hune, 2002; Johnson et al., 2007; Lee \& Davis, 2000), ethnic-based student organizations may give them the navigational capital (Yosso, 2005) to manage their college transition socially and academically.

Students in this study actively sought out, developed and valued peer (social) support, both in general and through the CSC, mirroring the importance of peer support identified by Chhuon, Hudley, Brenner, and Macias (2010). For instance, multiple students pointed to the role informal peer mentors played in validating their presence on campus, affirming that they could successfully negotiate the rigors and challenges of a college education. Peers also helped students learn about and manage the expectations of college work, served as study partners, and provide reassurance that they were cared for and had a "place" on the campus. Thus, peers were important validating agents, serving as sources of social and navigational capital.

However, participation in the CSC in particular was an essential validating agent in the lives of the students in this study. For these students, the CSC connected them to peers from the same background and culture, which was especially important given the fact that the Cambodian American students were underrepresented on the Sunnyview campus. Moreover, students noted that engagement in this organization and others contributed to their growth and learning. This finding echoes existing research suggesting student involvement contributes to students' talent development as they devote more time and energy to their campus lives (Astin, 1984; Rendon \& Jalomo, 1995).

At the same time, the CSC served as a source for strengthening students' familial capital as well. The CSC was a forum for students to learn about their culture and their language in a way at least some previously had not been able to do. Thus, students like Kiko and Michelle described one of the benefits of CSC involvement as being able to better relate to their families 
and their culture in general. In addition, the CSC (largely through their annual culture show) provided a way for students to engage their families in some part of their college experiencelinking families, peers, and the students. Involvement in the CSC did not just provide social and navigational capital; it was a tool for students to strengthen their familial and linguistic capital (Yosso, 2005) as well. Indeed, students' willingness to remain in the CSC despite family opposition suggests the students were at least intuitively aware of the varied educational, social, and cultural benefits of investing time and energy in campus life (Astin, 1984).

In summary, students in this study drew upon and actively cultivated multiple forms of capital (Yosso, 2005) and validating agents (Rendon, 1994) to facilitate their college success. They often did so with great sophistication, taking what they could from their families, developing networks of peers through involvement in organizations, and then leveraging their organizational involvement to try to connect further with their families. In accessing and nurturing multiple forms of cultural capital, the students accessed both internal (peers) and external (family) validating agents, who helped them succeed in college.

\section{Implications and Recommendations}

The findings of this study allow educators to gain insight into the experiences of Cambodian American college students and devise strategies to better serve them. Faculty and staff must recognize the need to advise students in a more holistic manner. Even though students show signs of academic success by passing their classes, they can also be simultaneously dealing with challenges that hinder their learning experiences. Establishing rapport and creating a healthy learning environment will greatly contribute to the student's academic success. Additionally, culture was significant to the participants and they were more responsive to any acknowledgement of Cambodia. The following sections outline the recommendations for practice for institutions with diverse AAPI student populations such as Sunnyview.

\section{Establishing Asian American and Pacific Islanders (AAPI) Student Coalition}

Although Cambodian American students had an ethnic-based student organization, they expressed having minimal representation on campus and feelings of being a minority at Sunnyview. There are over 20 AAPI ethnic-based student organizations on campus, yet they appear to be largely disconnected. These organizations need to connect and establish collaborative relationships with one another to increase their visibility on campus, reaching out to more students and providing a broader support network to enhance benefits of participation. This AAPI student coalition, composed of student leaders from all the ethnic-based organizations, is recommended to unite and advocate for the overall AAPI student population on campus. The proposal for an AAPI student coalition at Sunnyview will help serve the different Asian American and Pacific Islander organizations and increase their voices and concerns on campus. The student coalition can also spearhead events to promote all cultures at the institution to create a more inclusive campus and learning environment for diverse AAPI students.

\section{Developing Cultural Competence and Support on Campus}

Institutions with diverse AAPI populations need their faculty, staff, and community members to be culturally competent. Campus professionals can contribute in creating an inclusive learning 
environment by increasing their own knowledge about individual AAPI student groups such as Cambodian Americans. Students, staff, and faculty can attend cross-cultural trainings to engage in discourse about diversity and build relationships with other campus members. This will create a healthy learning environment where underrepresented AAPI students can develop a sense of belonging to the college community. Faculty and staff should be encouraged to support cultural events on campus to increase their cultural competency. Additionally, they can validate the students by attending student-led campus events to acknowledge the culture and hard work of their students. This type of learning can be fostered by the faculty and staff in partnership with the student leaders of the organizations.

\section{Implementing Culturally Inclusive Curriculum}

While Rendon (1994) points to both in-class and out-of-class validating agents and experiences, the former were notably sparse in the experiences of this study's participants. This heightens the importance of faculty involvement in developing and implementing culturally inclusive curriculum. Faculty can increase the cultural competency level of their students and validate their diverse students by implementing culturally inclusive course requirements in the curriculum. Faculty can incorporate assignments that acknowledge culture and diversity, such as having the students reflect on their cultural and family background. Moreover, the university student body will more likely be introduced to the cultural activities for educational purposes. Often times, school organizations coordinate cultural events to share with the campus community, but not many campus members attend. Faculty can facilitate and help increase interest in the students' efforts by encouraging students to attend for class credit. Culturally inclusive curriculum will benefit both the students involved in the organizations and the students in attendance.

\section{Advocating for Federal Funding Policy Change}

Institutions that serve more than one underrepresented student populations should not have to choose which student group to serve on their campus. For example, Hispanic-Serving Institutions (HSI) aim to serve Latino students and Asian American and Native American Pacific IslanderServing Institutions (AANAPISI) supports Asian American and Pacific Islander students. Institutions that meet the eligibility of being a HSI or AANAPISI can apply for federal grants. However, schools that are eligible for both grants must decide which student group will receive the funding since policy does not allow an institution to accept two of the same type of grants. By having institutions choose one marginalized group over another implies that one population is more valued and the other does not receive resources. Instead of limiting the resources for these underrepresented groups, a policy modification needs to be enacted for institutions that serve both populations to receive both grants. Each underrepresented population is different and has its own needs. Therefore, the restriction prevents the underrepresented group that was not chosen from receiving adequate resources and attention. Resources for these groups should not be competing against one another since they target different groups.

\section{Recommendations for Future Research}

This study has its limitations and the findings cannot be generalized to the overall Cambodian American student population. There needs to be additional studies on this student population to 
add to the dearth of literature in higher education. Future research on Cambodian American students should be conducted on multiple campuses to gain insights from a more diverse sample group in different institutions.

In addition, the participants in this study were hyperaware of their culture due to their involvement in the Cambodian Student Club and they may not represent the full student population accurately. A study that includes the comparison between students who are active and inactive in student life should be considered to collect experiences of both groups of students to gain more insight. Students in different majors and departments also experience their own unique challenges and a research that focuses on specific majors may provide better insight of the college experiences of Cambodian Americans. An exploration of the career choice of Cambodian Americans may lead to additional understanding of this student group and their college pursuits.

Finally, family is a significant influence in the lives of the Cambodian American college students and their perspectives are critical to understand the student's college choice and college experiences. The contributions of the parents of these students will help researchers and educators better understand the role of familial influences. Since family is such a significant factor in their college lives, gathering the thoughts of the parents can provide more insights on the relationships between family and students on their campus involvement and academic endeavors.

\section{Conclusion}

This exploratory study examined the experiences of first-generation Cambodian American college students through the lens of Rendon's (1994) Validation Theory and Yosso's (2005) Community Cultural Wealth Theory. Findings in this study allow educators to gain insight into the obstacles of first-generation Cambodian American students and the factors that contribute to their success in college. In this case, study participants were actively engaged in accessing multiple forms of cultural capital to validate their college experience and support their success. The study also highlights the diversity within Asian Americans and the need to be familiar with the specific experiences that affect the students' lives. Although findings in this study cannot be generalized to the entire Cambodian American student population, they call for more attention and resources to underrepresented Asian American and Pacific Islander students.

\section{References}

Astin, A. (1982). Minorities in higher education. San Francisco, CA: Jossey-Bass.

Astin, A. W. (1984). Student involvement: A developmental theory for higher education. Journal of College Student Development, 25, 297-308.

Brydolf, C. (2009). Getting real about the 'model minority'. Education Digest, 74(5), 37-44.

Chhuon, V., Dosalmas, A., \& Rinthapol, N. (2010). Factors supporting academic engagement among Cambodian American high school youth. Journal of Southeast Asian American Education \& Advancement, 5, 1-14.

Chhuon, V., \& Hudley, C. (2008). Factors supporting Cambodian American students' successful adjustment into the university. Journal of College Student Development, 49(1), 15-30. doi:10.1353/csd.2008.0005 
Chhuon, V., \& Hudley, C. (2010). Asian American ethnic options: How Cambodian students negotiate ethnic identities in a U.S. urban school. Anthropology \& Education Quarterly, 41(4), 341-359. doi:10.1111/j.1548-1492.2010.01096.x

Chhuon, V., \& Hudley, C. (2011). Ethnic and panethnic Asian American identities: Contradictory perceptions of Cambodian students in urban schools. Urban Review: Issues and Ideas in Public Education, 43(5), 681-701.

Chhuon, V., Hudley, C., Brenner, M. E., \& Macias, R. (2010). The multiple worlds of successful Cambodian American students. Urban Education, 45(30), 30-57. doi: $10.1177 / 0042085909352583$

Chhuon, V., Kyratzis, A., \& Hudley, C. (2010). Sources of coherence in the life stories of Cambodian American women at the university. Journal of Language, Identity, and Education, 9(5), 347-362.

Hune, S. (2002). Demographics and diversity of Asian American college students. In M. K. McEwen, C. M. Kodama, A. N. Alvarez, S. Lee, \& C. Liang (Vol. Eds.), New Directions for student services: Vol. 97. Working with Asian American college students (pp. 11-20). San Francisco, CA: Jossey-Bass.

Johnson, D. R., Soldner, M., Leonard, J., Alvarez, P., Inkelas, K., Rowan-Kenyon, H., \& Longerbeam, S. (2007). Examining sense of belonging among first-year undergraduates from different racial/ethnic groups. Journal of College Student Development, 48(5), 525542.

Kiang, P. (1992). Issues of curriculum and community for first-generation Asian Americans in college. New Directions For Community Colleges, (80), 97-112.

Lee, R. M., \& Davis, C. (2000). Cultural orientation, past multicultural experience, and a sense of belonging on campus for Asian American college students. Journal of College Student Development, 41(1), 110-115.

Lee, S. (1996). Unraveling the model minority stereotype: Listening to Asian American youth. New York, NY: Teachers College Press.

Leung, A. N., Wong, S. S., Wong, I. W., \& McBride-Chang, C. (2009). Filial piety and psychosocial adjustment in Hong Kong Chinese early adolescents. The Journal of Early Adolescence, 30(5), 651- 667. doi: 10.1177/0272431609341046

Lincoln, Y. S., \& Guba, E. G. (1985). Naturalistic Inquiry. Newbury Park, CA: Sage Publications.

Museus, S. D., \& Chang, M. J. (2009). Rising to the challenge of conducting research on Asian Americans in higher education. New Directions for Institutional Research, 142, 95-105.

Museus, S. D., \& Kiang, P. N. (2009). Deconstructing the model minority myth and how it contributes to the invisible minority reality in higher education research. New Directions for Institutional Research, 142, 5-15.

Nakanishi, D. (1995). A quota on excellence? The Asian America admissions debate. In D. T. Nakanishi \& T. Nishida (Eds.), The Asian American educational experience (pp. 273284). New York, NY: Routledge.

National Center for Education Statistics. (2010). The nation's report card: Reading 2009: National assessment of educational progress at grades 4 and 8 (NCES 2010-458). Washington, DC: U.S. Department of Education, Institute of Education Sciences.

National Commission on Asian American and Pacific Islander Research in Education. (2011). CARE annual report. Retrieved from http://www.nyu.edu/projects/care/ 
Ngo, B. (2006). Learning from the margins: The education of Southeast and South Asian Americans in context. Race, Ethnicity \& Education, 9(1), 51-65.

Ngo, B., \& Lee, S. J. (2007). Complicating the image of model minority success: A review of Southeast Asian American education. Review of Educational Research, 77(4), 415-453.

Reeves, T, \& Bennett, C. (2004). We the people: Asians in the United States, Census 2000 Special Reports. Washington, DC: U.S. Census Bureau.

Rendon, L. I., \& Jalomo, R. R. (1995). Validating student experience and promoting progress, performance, and persistence through assessment. Paper prepared for the National Center for Postsecondary Teaching, Learning and Assessment Institute, Los Angeles, CA.

Rendon, L. I. (1994). Validating culturally diverse students: Toward a new model of learning and student development. Innovative Higher Education, 19(1), 33-51.

Saldaña, J. (2009). The coding manual for qualitative researchers. Los Angeles, CA: Sage Publications.

Southeast Asia Resource Action Center. (2011). Southeast Asian Americans at a glance. Washington, DC: Author.

Takaki, R. (1998). Strangers from a different shore. New York, NY: Little Brown.

Tang, K., \& Kao, D. (2012). Ethnicity, gender, and the education of Cambodian American students in an urban high school. Journal of Southeast Asian American Education \& Advancement. 7, 1-24.

Teranishi, R. T. (2002). The myth of the super minority: Misconceptions about Asian Americans. The College Board Review, 195, 17-21.

Teranishi, R. T. (2004). Yellow and brown: Residential segregation and emerging Asian American immigrant populations. Equity and Excellence in Education, 37(3), 255-263.

Teranishi, R. T. (2012). Asian American and Pacific Islander students and the institutions that serve them. Change, 44(2), 16-22.

Um, K. (2003). A dream denied: educational experiences of Southeast Asian American youth: Issues and recommendations. Washington, DC: Southeast Asia Resource Action Center.

U.S. Census Bureau. (2011, April 29). Profile America facts for features: Asian/Pacific American Heritage Month: May 2011. Retrieved from http://www.

census.gov/newsroom/releases/archives/facts_for_features_special_editions/cb11ff06.html

Wright, W., \& Boun, S. (2011). Southeast Asian American education 35 years after initial resettlement: Research report and policy recommendations. Journal of Southeast Asian American Education \& Advancement, 6, 1-77.

Yeh, T. L. (2004). Issues of college persistence between Asian and Asian Pacific American students. Journal of College Student Retention: Research, Theory and Practice, 6(1), 8196.

Yosso, T. (2005). Whose culture has capital? A critical race theory discussion of community cultural wealth. Race, Ethnicity and Education, 8(1), 69-91. 


\begin{abstract}
About the Authors
Jennifer Tang earned her master's degree in Student Development in Higher Education from California State University, Long Beach (CSULB). Her interests in higher education include promoting access and equity for college students, specifically first-generation students, and advocating for underrepresented student populations. She is currently the Assistant Director for the Single Subject Credential Program at CSULB.

Simon Kim is a professor of educational psychology in the Department of Advanced Studies in Education and Counseling at California State University, Long Beach. He maintains an active research agenda in educational partnerships and accountability, in studies of culturally and linguistically diverse students, and in the conceptualization and practice of evaluation of educational programs. He currently serves on the steering committee of the CSU Asian American and Pacific Islander Initiative.

Don Haviland is an associate professor in the Department of Educational Leadership at California State University, Long Beach, where he teaches courses on leadership, research methods, and program assessment. His scholarly interests include innovation and change in higher education, faculty development, and program assessment and effectiveness.
\end{abstract}




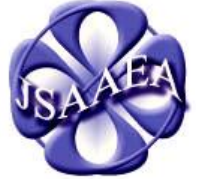

Volume 8 (2013)

\section{Journal of Southeast Asian American Education \& Advancement} WWW.JSAAEA.org

\section{Editor}

Dr. Wayne E. Wright

University of Texas at San Antonio

Associate Editors

Dr. Chhany Sak-Humphry

University of Hawaii at Manoa

Dr. Phitsamay Sychitkokhong Uy

University of Massachusetts, Lowell

Book Review Editor

Dr. Vichet Chhuon

University of Minnesota

Creative Works Editor

Bryan Thao Worra

Lao Assistance Center

Special Advisor

Gregory Green

Curator, Echols Collection on Southeast Asia, Cornell University Library

Journal Manager

Yeng Yang

University of Texas at San Antonio
A peer-reviewed

scholarly journal published by the

National Association

for the Education \&

Advancement of

Cambodian, Laotian,

and Vietnamese

Americans (NAFEA)

Comments and questions for the editorial staff may be directed to jsaaea@ lists.sis.utsa.edu

\section{Editorial Review Board}

Dr. Steve Arounsack

California State University, Stanislaus

Dr. Phala Chea

Lowell Public Schools

Dr. Loan Dao

University of Massachusetts, Boston

Dr. Changming Duan

University of Missouri, Kansas City

Dr. Jeremy Hein

University of Wisconsin - Eau Claire

Dr. Samlong Inthaly

Minneapolis Public Schools

Dr. Kevin K. Kumashiro

University of Illinois, Chicago
Dr. Carl L. Bankston III

Tulane University

Dr. George Chigas

University of Massachusetts, Lowell

Dr. Hien Duc Do

San Jose State University

Dr. Sophal Ear

U.S. Naval Postgraduate School

Dr. Nancy H. Hornberger

University of Pennsylvania

Dr. Peter Nien-Chu Kiang

University of Massachusetts, Boston

Dr. Ha Lam

Arizona State University 


\author{
Dr. Jonathan H. X. Lee \\ San Francisco State University \\ Dr. Sue Needham \\ California State University, Dominguez Hills \\ Dr. Max Niedzwiecki \\ Daylight Consulting Group \\ Dr. Clara Park \\ California State University, Northridge \\ Dr. Mark Pfeifer \\ SUNY Institute of Technology \\ Dr. Loan T. Phan \\ University of New Hampshire \\ Dr. Karen Quintiliani \\ California State University, Long Beach \\ Dr. Angela Reyes \\ Hunter College, The City University of New York \\ Dr. Fay Shin \\ California State University, Long Beach \\ Dr. Cathy J. Schlund-Vials \\ University of Connecticut, Storrs \\ Dr. Yer J. Thao \\ Portland State University \\ Dr. Myluong Tran \\ San Diego State University \\ Dr. Khatharya Um \\ University of California, Berkeley \\ Dr. Linda Trinh Vo \\ University of California, Irvine \\ Dr. Yang Sao Xiong \\ University of Wisconsin-Madison
}

Dr. Kou Yang

\author{
Dr. Stacey Lee \\ University of Wisconsin, Madison \\ Dr. Bic Ngo \\ University of Minnesota \\ Dr. Leakhena Nou \\ California State University, Long Beach \\ Dr. Isabelle Thuy Pelaud \\ San Francisco State University \\ Dr. Giang Pham \\ University of Minnesota \\ Dr. Bounlieng Phommasouvanh \\ Minnesota Department of Education \\ Dr. Kalyani Rai \\ University of Wisconsin, Milwaukee \\ Dr. Soveacha Ros \\ Royal University of Phnom Penh \\ Dr. Nancy J. Smith-Hefner \\ Boston University \\ Dr. Christine Su \\ Ohio University \\ Dr. Loan Tran \\ University of California, Riverside \\ Dr. Tinou Tran \\ Alief Independent School District \\ Dr. Silvy Un \\ Frost Lake Elementary School \\ Dr. Terrence G. Wiley \\ Center for Applied Linguistics \\ Dr. Zha Blong Xiong \\ University of Minnesota
}

California State University, Stanislaus

\section{Doctoral Student Editorial Review Board}

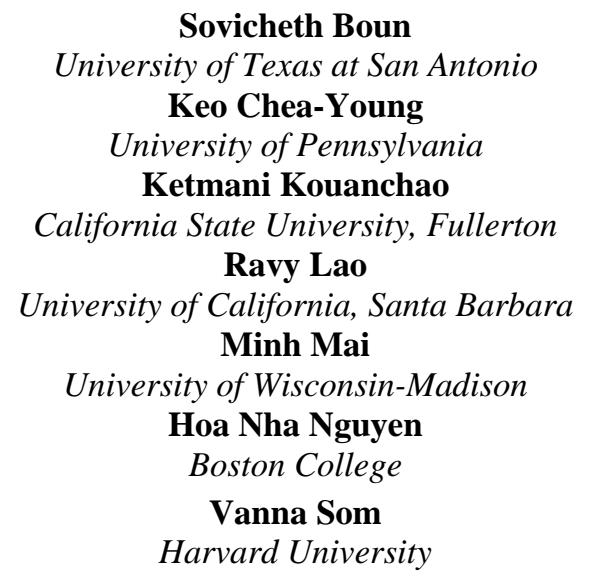

Sovicheth Boun

University of Texas at San Antonio

Keo Chea-Young

University of Pennsylvania

Ketmani Kouanchao

California State University, Fullerton

Ravy Lao

University of California, Santa Barbara

Minh Mai

University of Wisconsin-Madison

Hoa Nha Nguyen

Boston College

Vanna Som

Harvard University

\author{
Virak Chan \\ University of Texas at San Antonio \\ Annie BichLoan Duong \\ San Joaquin County Office of Education \\ Peter Tan Keo \\ Columbia University \\ Monirith Ly \\ Texas State University-San Marcos \\ Thien-Huong Ninh \\ University of Southern California \\ Malaphone Phommasa \\ University of California, Santa Barbara \\ Alisia Tran \\ University of Minnesota
}

Krissyvan Truong

Claremount Graduate University 